\title{
Pengaruh Kinerja Petugas Cleaning Service Terhadap Kepuasan Penumpang Ekonomi Kapal Motor Kelud PT. PELNI (Persero)
}

\author{
Irsyad Ardy Haryanto ${ }^{\mathrm{a}, 1^{*}}$, Heni Pridia Rukmini Sari ${ }^{\mathrm{b} 2}$ \\ ${ }^{\text {a }}$ Prodi Hospitalit dan Pariwisata - Institut STIAMI Jakarta \\ ${ }^{\mathrm{b}}$ Prodi Hospitalit dan Pariwisata - Institut STIAMI Jakarta \\ 1 irsyadardy@gmail.com \\ *corresponding author
}

\section{ARTICLE INFO}

Article history

Received

Revised

Accepted

Keywords

Cleaning Service Officers Performance

Customer Satisfaction

Economy Passenger

Water Transportation

KM Kelud PT PELNI

\section{ABSTRACT}

The purpose of this study was to determine the Effect of Cleaning Service Officers Performance on Passenger Economic Satisfaction MV. Kelud PT. PELNI (Persero). Data collection method to test the hypothesis using a questionnaire aimed at 90 respondents of sea transportation service users, especially economy passengers MV. Kelud PT. PELNI (Persero).

$T$ Test Results in this study have a calculated $t$ value of 9,686. at the error level (alpha) 0.05 with the number of samples 90 and the number of independent variables 1 , the value of $t$ table is (1.987). Because the value of $t$ arithmetic $(\mathbf{9 , 6 8 6 )}$ is greater than t table $(\mathbf{1 , 9 8 7 )}$ then $\mathrm{Hl}$ is accepted, meaning that there is an influence between Performance $(X)$ on Customer Satisfaction (Y). The results of the calculation of the coefficient determination of the variable Influence the Performance of Cleaning Service Officers on Passenger Economic Satisfaction MV. Kelud PT. PELNI (Persero) is $\mathbf{5 1 . 6 \%}$ It shows that the Performance of Cleaning Service Personnel variables has a positive and significant effect on the satisfaction of KM economic passengers MV. Kelud PT. PELNI (Persero) while the rest is influenced by other factors. As well as the recapitulation of the average score on the economic passenger satisfaction indicator is 4.06 (Good) which shows that in general, economy passengers of MV. Kelud PT. PELNI (Persero) is satisfied with the performance of the Cleaning Service Officers.

\section{Pendahuluan}

\subsection{Latar Belakang}

Indonesia dikenal sebagai negara kepulauan yang membentang dari barat sampai ke timur. Posisi Indonesia juga dinilai sangat strategis karena berada di sepanjang garis katulistiwa. Indonesia juga terletak di antara dua samudera, yaitu Samudera Hindia dan Samudera Pasifik serta di antara dua benua, Asia dan Australia. Indonesia juga memiliki potensi yang sangat besar sebagai poros maritim dunia yang merupakan gagasan strategis untuk menjamin konektivitas antar pulau, pengembangan industri perkapalan dan perikanan, perbaikan transportasi laut dan keamanan maritim.

Sebagai negara kepulauan, tentunya Indonesia membutuhkan transportasi laut yang dapat menghubungkan antar pulau-pulaunya. Moda transportasi laut berupa kapal penumpang ini sangat 
diminati karena mempunyai daya tampung yang lumayan banyak dan harga tiketnya relatif terjangkau.

Seperti diketahui, operator kapal penumpang terbesar di Indonesia adalah PT. PELNI (Persero) yang merupakan sebuah perusahaan BUMN milik Indonesia. PT. PELNI (Persero) melayani jasa pengangkutan penumpang reguler dan kapal perintis yang ditujukan sebagai kapal penghubung kapal penumpang reguler menuju rute-rute terluar yang sulit dijangkau oleh kapal penumpang reguler. Meskipun merupakan perusahaan BUMN, PT. PELNI (Persero) tetap mengutamakan kenyamanan penumpang terutama soal kebersihan di setiap areal kapal penumpang.

Kapal Motor (KM) Kelud dengan rute pelayaran dari Pelabuhan Tanjung Priok, Jakarta, menuju ke Pelabuhan Bandar Deli di Medan dengan waktu tempuh 5 hari 3 malam merupakan kapal penumpang berkapasitas 2000 penumpang dengan rincian penumpang ekonomi sejumlah 804 orang, penumpang kelas I 144 orang, penumpang kelas II 364 orang dan penumpang kelas III 594 orang. Total keseluruhan penumpang berjumlah 1906 orang ditambah anak buah kapal berjumlah 157 orang. Dari jumlah kapasitas data muatan penumpang tersebut, ruang penumpang ekonomi memiliki kapasitas paling banyak dan sering terisi penuh. Ini dikarenakan harga tiket ekonomi KM. Kelud relatif terjangkau oleh masyarakat kalangan menengah ke bawah. Harga tiket dengan tujuan ke Medan hanya Rp530.000 untuk dewasa dan Rp53.000 untuk bayi. Banyaknya penumpang di kelas ekonomi membuat kebersihan di kelas ini menjadi fokus utama PT. PELNI (Persero).

PT. PELNI (Persero) mengelola kebersihan di atas kapal penumpang bersama dengan sama dengan anak usahanya yang bergerak di bidang managing service penyedia jasa petugas cleaning service di atas kapal. Petugas cleaning service yang bertugas di atas KM. Kelud berjumlah 18 orang terdiri dari 17 petugas dan 1 mandor lapangan dengan area bekerja meliputi ruang tidur dan kamar mandi penumpang ekonomi yang berlokasi di dek (lantai) 2 sampai dengan 4 kapal. Petugas cleaning sevice ini bekerja selama 24 jam dalam 1 hari dan dibagi dalam 3 shift, yaitu Shift I yang merupakan General Cleaning pada pukul 06.00 s/d 14.00, Shift II Maintenance Cleaning pukul $14.00 \mathrm{~s} / \mathrm{d} 22.00$, dan Shift III Insidental pukul $22.00 \mathrm{~s} / \mathrm{d}$ 06.00. Kinerja petugas cleaning service sangat ditentukan oleh oleh jumlah penumpang ekonomi yang on board. Pada masa peak season, jumlah penumpang ekonomi bisa melebihi kapasitas seat yang tersedia sehingga banyak penumpang non seat yang memenuhi lorong-lorong area ekonomi. Ini mengakibatkan pelaksanaan pekerjaan cleaning service menjadi terkendala dan kebersihan kapal tidak maksimal.

Jumlah petugas cleaning service yang tidak sebanding dengan ruang lingkup pekerjaan serta jumlah penumpang menjadi kendala dalam pelaksanaan pekerjaan. Lorong-lorong di ruang penumpang ekonomi yang berada di dek 2 sampai dek 4 kerap dijumpai gunungan sampah sisa makanan penumpang yang menumpuk dan berbau kurang sedap. Hal ini disebabkan kapasitas tempat sampah yang tidak banyak dan dampak dari kurangnya personil cleaning service untuk mengangkut sampah ke tempat pembuangan akhir.

Dari penjelasan di atas dapat diketahui bahwa kinerja petugas cleaning service secara tidak langsung menjadi faktor yang memengaruhi kepuasan penumpang ekonomi terhadap pelayanan jasa angkutan kapal penumpang. Jika kinerja petugas cleaning service maksimal kondisi ruang ekonomi akan nyaman dan jumlah keluhan akibat ketidaknyamanan atas kebersihan ruang ekonomi akan berkurang. Begitu juga sebaliknya, jika hasil pekerjaan petugas cleaning service kurang maksimal maka tingkat keluhan penumpang ekonomi KM. Kelud akan semakin meningkat.

\subsection{Hospitaliti}

Dari beberapa literatur keilmuan maupun asal kosa katanya, diperoleh pengertian hospitality dalam berbagai pemahaman. Menurut Hershberger (Hermawan, 2017:11) hospitality berasal dari 
kata Latin hospitium (kata sifatnya hospitalis), dari hospes, yang artinya "tamu" atau "tuan rumah". Konsep ini juga dipengaruhi oleh kata Yunani Xenos, yang menunjuk kepada orang asing yang menerima sambutan atau yang melakukan penyambutan terhadap orang lain.

Menurut Pendit (2017:152) hospitality memiliki arti keramah-tamahan, kesopanan, keakraban dan juga rasa saling menghormati. Jika dikaitkan dengan industri pariwisata, dapat diibaratkan bahwa hospitality merupakan roh, jiwa, semangat dari pariwisata. Tanpa adanya hospitality dalam pariwisata, maka seluruh produk yang ditawarkan dalam pariwisata itu seperti benda mati yang tidak memiliki nilai untuk dijual.

Dalam bahasa Inggris hospitality juga didefinisikan sebagai kata friendly yang artinya 'ramah' yang murah hati atau dermawan dan memberikan hiburan kepada tamu atau orang baru. Kadangkadang sering digunakan untuk memberikan perlakuan istimewa terhadap tamu yang tinggal dan menggunakan fasilitas keramahtamahan. Adapun industri hospitaliti dapat diartikan sebagai perusahaan yang terlibat dalam penyediaan jasa untuk tamu (Conciere Oxford Dictionary, 2017).

Selain itu menurut Tim Dosen Sekolah Tinggi Pariwisata Bali (2016) hospitality merupakan interaksi antara tuan rumah (hosts) dengan tamu (guests) pada saat yang bersamaan mengonsumsi makanan/minuman dan akomodasi.

\subsection{Pelayanan Jasa}

Menurut Kotler (Lupiyoadi, 2014:7) pelayanan jasa adalah setiap tindakan atau kegiatan yang dapat ditawarkan oleh satu pihak kepada pihak lain, pada dasarnya tidak berwujud dan tidak mengakibatkan perpindahan kepemilikan apapun. Produksi jasa mungkin berkaitan dengan produk fisik atau tidak.

Sedangkan menurut Tjiptono (2014:26) pelayanan jasa sebagai setiap tindakan atau perbuatan yang dapat ditawarkan oleh suatu pihak lain yang pada dasarnya bersifat intangible (tidak berwujud fisik) dan tidak menghasilkan kepemilikan sesuatu.

Sedangkan menurut Zeithaml dan Bitner (Lupiyoadi, 2013:7) mendefinisikan "Service is all economic activities whose output is not a physical product or construction is generally consumed at that time it is produced, and provides added value in forms (such as convenience, amusement, comfort or health)". Artinya, pelayanan jasa merupakan semua aktivitas ekonomi yang hasilnya bukan berbentuk produk fisik atau konstruksi, yang umumnya dihasilkan dan dikonsumsi secara bersamaan serta memberikan nilai tambah (misalnya kenyamanan, hiburan, kesenangan, atau kesehatan) konsumen".

\subsection{Transportasi dan Kapal Angkutan Penumpang}

Transportasi adalah pemindahan manusia atau barang dengan menggunakan wahana yang digerakkan oleh manusia atau mesin. Transportasi digunakan untuk memudahkan manusia untuk melakukan aktivitas sehari-hari. Banyak ahli telah merumuskan dan mengemukakan pengertian transportasi, namun para ahli juga memiliki pandangannya masing-masing yang mempunyai perbedaan dan persamaan antara yang satu dengan lainnya (Andriansyah, 2015).

Kata transportasi berasal dari bahasa Latin, yaitu transportare yang mana "trans" berarti mengangkat atau membawa. Jadi transportasi adalah membawa sesuatu dari satu tempat ke tempat yang lain. Menurut Adisasmita (2011) transportasi atau transport diartikan sebagai tindakan atau kegiatan mengangkut atau memindahkan muatan (barang dan orang) dari satu tempat ke tempat lain, atau dari tempat asal ke tempat tujuan. Tempat asal dapat merupakan daerah produksi, dan tempat tujuan adalah daerah konsumen (atau pasar). Tempat asal dapat pula merupakan daerah perumahan (permukiman), sedangkan tempat tujuan adalah tempat bekerja, kantor, sekolah, kampus, rumah sakit, pasar, toko, pusat perbelanjaan, hotel, pelabuhan, bandar udara, dan masih 
banyak sekali yang lainnya, ataupun dalam arah sebaliknya, yaitu tempat tujuan merupakan tempat asal dan tempat asal merupakan tempat tujuan.

Menurut Soesilo (Rifusa, 2010) transportasi merupakan pergerakan tingkah laku orang dalam ruang baik dalam membawa dirinya sendiri maupun membawa barang-barang. Selain itu, menurut Tamin (dalam Agus Imam Rifusa, 2010) mengungkapkan bahwa prasarana transportasi mempunyai dua peran utama, yaitu (1) sebagai alat bantu untuk mengarahkan pembangunan di daerah perkotaan dan (2) sebagai prasarana bagi pergerakan manusia dan/atau barang yang timbul akibat adanya kegiatan di daerah perkotaan tersebut.

Pada dasarnya transportasi merupakan sarana penghubung atau yang menghubungkan antara daerah produksi dan pasar, atau dapat dikatakan mendekatkan daerah produksi dan pasar, atau seringkali dikatakan menjembatani mobilitas masyarakat.

Transportasi telah digunakan dalam kehidupan masyarakat sejak dulu, hanya saja alat angkut yang dimaksud bukan seperti sekarang ini. Sebelum tahun 1800, alat pengangkut yang digunakan adalah tenaga manusia, hewan dan sumber tenaga dari alam. Antara tahun 1800-1860 transportasi telah mulai berkembang dengan dimanfaatkannya sumber tenaga mekanis seperti kapal laut.

Kapal laut angkutan penumpang adalah kapal yang digunakan untuk mengangkut penumpang melalui jalur perairan baik sungai, danau, maupun laut. Untuk meningkatkan efisiensi atau melayani keperluan yang lebih luas kapal penumpang dapat berupa kapal Ro-Ro, ataupun untuk perjalanan pendek terjadwal dalam bentuk kapal feri (Transmedia, 2012). Beberapa pengertian kapal angkutan penumpang adalah sebagai berikut:

1. Menurut Peraturan Pemerintah Republik Indonesia Tahun 2010 tentang Angkutan Perairan, kapal laut angkutan penumpang adalah kegiatan angkutan yang menurut kegiatannya melayani angkutan laut baik dalam negeri maupun luar negeri.

2. Menurut Peraturan Menteri Perhubungan Nomor 115 Tahun 2016, pengertian kapal adalah kendaraan air dengan bentuk dan jenis tertentu, yang digerakan dengan tenaga angin, tenaga mekanik, energi lainnya, ditarik dan atau ditunda. Sedangkan kapal penumpang adalah kapal yang dibangun dan dikonstruksikan serta mempunyai fasilitas akomodasi untuk mengangkut penumpang lebih dari 12 orang.

\subsection{Kinerja}

Menurut Siswanto (Sandy, 2015:11) kinerja ialah prestasi yang dicapai oleh seseorang dalam melaksanakan tugas dan pekerjaan yang diberikan kepadanya. Sedangkan menurut Rivia (Sandy, 2015:12) kinerja atau prestasi kerja adalah hasil atau tingkatan keberhasilan seseorang secara keseluruhan selama periode tertentu di dalam melaksanakan tugas dibandingkan dengan berbagai kemungkinan, seperti standar hasil kerja, target atau sasaran atau kriteria yang telah ditentukan terlebih dahulu dan disepakati bersama.

Selain itu kinerja atau performance menurut Abdullah (2014:3) merupakan gambaran dari tingkat pencapaian pelaksanaan suatu program kegiatan atau kebijakan dalam mewujudkan sasaran, tujuan atau visi dan misi organisasi yang dituangkan melalui perencanaan strategis suatu organisasi.

\section{a. Faktor-faktor yang Memengaruhi Kinerja}

Kinerja individu maupun kelompok kerja dalam organisasi menggambarkan kinerja organisasi sesungguhnya. Untuk mencapai standar tertentu yang telah ditetapkan organisasi, ada beberapa hal yang memengaruhi individu maupun organisasi tersebut mencapai standar kinerja atau hasil kerja tertentu. Menurut Anwar Prabu Mangkunegara (2013:67) ada 2 faktor yang mempengaruhi kinerja antara lain:

1. Faktor kemampuan: Secara psikologis, kemampuan karyawan terdiri dari potensi Intelegent Quotient (IQ), serta kemampuan pengetahuan dan keterampilan. 
2. Faktor motivasi: Motivasi terbentuk dari sikap seorang karyawan dalam menghadapi situasi kerja. Artinya, karyawan harus memiliki sikap mental yang siap, mampu secara fisik, memahami tujuan utama dan target kerja yang akan dicapai, mampu memanfaatkan, dan menciptakan situasi kerja.

\section{b. Indikator Kinerja}

Mangkunegara (2013:75) mengemukakan bahwa indikator kinerja, yaitu:

1. Kualitas

Kinerja adalah seberapa baik seorang karyawan mengerjakan apa yang seharusnya dikerjakan.

2. Kuantitas

Kuantitas kerja adalah seberapa lama seorang pegawai bekerja dalam seharinya. Kuantitas kerja ini dapat dilihat dari kecepatan kerja setiap pegawai itu masing-masing.

3. Pelaksanaan Tugas

Pelaksanaan tugas adalah seberapa jauh karyawan mampu melakukan pekerjaannya dengan akurat atau tidak ada kesalahan.

\subsection{Cleaning Service}

Cleaning Service adalah pelayanan yang diberikan terhadap kebersihan suatu gedung atau bangunan lainnya, yang dilakukan secara seksama dan menyeluruh dengan bantuan alat-alat kebersihan mesin non mesin serta bahan kimia (chemical) yg dilakukan oleh seorang petugas atau perawat kebersihan (cleaner). Tujuan cleaning service adalah menciptakan $5 \mathrm{~K}$ yaitu Kebersihan, kerapihan, keindahan, keamanan, dan kenyamanan pada gedung atau bangunan, yg dilakukan oleh seorang cleaner. Tugas pokok cleaner adalah menjaga dan merawat kebersihan masing-masing area, sesuai dengan penempatan, (plotting) dan prosedur yang sudah ditentukan oleh atasan (HES Indonesia, 2017).

\subsection{Kepuasan Pelanggan}

Menurut Kotler (2012) kepuasan pelanggan adalah perasaan senang atau kecewa seseorang yang muncul setelah membandingkan kinerja (hasil) produk yang dipikirkan terhadap kinerja atau hasil yang diharapkan.

Kata kepuasan (satisfaction) berasal dari bahasa latin "satis" (artinya cukup baik, memadai) dan "facio" (melakukan atau membuat). Kepuasaan dapat diartikan sebagai upaya pemenuhan sesuatu atau membuat sesuatu memadai (Tjiptono, 2011).

Sedangkan menurut Rahmayanty (2010:32) pelanggan adalah orang yang sudah pernah atau telah membeli dan menggunakan suatu produk barang atau jasa pada suatu perusahaan.

Menurut Engel dikutip dari Tjiptono (2010:127) konsep kepuasan pelanggan masih bersifat abstrak. Kepuasan pelanggan merupakan evaluasi pembeli dimana alternatif yang dipilih sekurangkurangnya memberikan hasil yang sama atau melampaui harapan pelanggan, sedangkan ketidak puasan timbul apabila hasil yang diperoleh tidak memenuhi harapan pelanggan.

\section{a. Faktor-Faktor yang Memengaruhi Kepuasan Pelanggan}

Menurut Sugiarto (Lupiyoadi, 2010) bahwa pelayanan yang baik akan dapat menciptakan loyalitas pelanggan yang semakin melekat erat dan pelanggan tidak berpaling pada perusahaan lain. Ikatan emosional tersebut merupakan wujud dari loyalitas yang ditunjukan konsumen kepada 
perusahaan sebagai bukti kepuasan atas kinerja produk yang diterimanya. Penjual atau produsen jasa perlu menguasai unsur-unsur berikut:

1. Kecepatan

Kecepatan adalah waktu yang digunakan dalam melayani konsumen atau pelanggan minimal sama dengan batas waktu standar pelayanan yang ditentukan oleh perusahaan.

2. Ketepatan

Kecepatan tanpa ketepatan dalam bekerja tidak menjamin kepuasan para pelanggan. Oleh karena itu, ketepatan sangatlah penting dalam pelayanan.

3. Keamanan

Dalam melayani para konsumen diharapkan perusahaan dapat memberikan perasaan aman untuk menggunakan produk atau jasa.

4. Keramahtamahan

Dalam melayani pelanggan, karyawan perusahaan dituntut untuk mempunyai sikap sopan dan ramah. Oleh karena itu, keramahtamahan sangat penting apalagi pada perusahaan yang bergerak pada bidang jasa.

5. Kenyamanan

Rasa nyaman timbul jika seseorang merasa diterima apa adanya. Dengan demikian perusahaan harus dapat memberikan rasa nyaman pada konsumen.

\section{b. Indikator Kepuasan Pelanggan}

Hawkins dan Lonney dikutip (Tjiptono, 2011) mengatakan bahwa atribut pembentuk kepuasan terdiri dari:

1. Kesesuaian harapan

Merupakan tingkat kesesuaian antara kinerja produk yang diharapkan oleh pelanggan dengan yang dirasakan oleh pelanggan, meliputi:

- Produk yang diperoleh sesuai atau melebihi dengan yang diharapkan.

- Pelayanan oleh karyawan yang diperoleh sesuai atau melebihi dengan yang diharapkan.

- Fasilitas penunjang yang didapat sesuai atau melebihi yang diharapkan.

2. Minat berkunjung kembali

Merupakan kesediaan pelanggan untuk berkunjung kembali atau melakukan pembelian ulang terhadap produk/ jasa terkait meliputi:

- Berminat untuk berkunjung kembali karena pelayanan yang diberikan oleh karyawan memuaskan;

- Berminat untuk berkunjung kembali karena nilai dan manfaat yang diperoleh setelah mengonsumsi produk;

- Berminat untuk berkunjung kembali karena fasilitas penunjang yang disediakan memadai.

3. Kesediaan merekomendasikan

- Menyarankan teman atau kerabat untuk membeli produk yang ditawarkan karena pelayanan yang memuaskan;

- Menyarankan teman atau kerabat untuk membeli produk yang ditawarkan karena fasilitas penunjang yang disediakan memadai;

- Menyarankan teman atau kerabat untuk membeli produk yang ditawarkan karena nilai atau manfaat yang didapat setelah mengkonsumsi sebuah produk jasa 


\section{Metode Penelitian}

Metode yang digunakan dalam penelitian ini adalah metode asosiasi kausal serta menggunakan pendekatan kuantitatif. Metode asosiasi kausal adalah penelitian yang digunakan untuk membuktikan sejauh mana hubungan antara dua variabel atau lebih. Hubungan kausal adalah hubungan yang bersifat sebab akibat. Dalam penelitian ini terdapat variabel independent (yang memengaruhi) dan dependent (dipengaruhi) (Sugiyono, 2013:2).

Permasalahan yang akan dikaji oleh peneliti merupakan masalah yang bersifat sosial dan dinamis. Oleh karena itu, peneliti memilih menggunakan metode penelitian kuantitatif untuk menentukan cara mencari, mengumpulkan, mengolah, dan menganalisis data hasil penelitian tersebut. Tujuan adalah untuk memberikan kemudahan dalam mengkaji kondisi dengan teliti.

Menurut Sugiyono (2010), metode penelitian kuantitatif dapat diartikan sebagai metode penelitian yang berlandaskan pada filsafat positivisme, digunakan untuk meneliti pada populasi atau sampel tertentu. Teknik pengambilan sampel pada umumnya dilakukan secara random, pengumpulan data menggunakan instrumen penelitian analisis data bersifat kuantitatif atau statistik dengan tujuan untuk menguji hipotesis yang telah ditetapkan. Hal ini sesuai dengan pendapat Arikunto (2016:12) yang mengemukakan penelitian kuantitatif adalah pendekatan penelitian yang banyak dituntut menggunakan angka, mulai dari pengumpulan data, penafsiran terhadap data tersebut, serta penampilan hasilnya.

Selanjutnya Sugiyono (2010:61) menyampaikan bahwa variabel penelitian dalam penelitian kuantitatif dapat dibedakan menjadi dua macam, yaitu:

1. Variabel bebas (independent variable) yang merupakan variabel yang mempengaruhi atau menjadi sebab perubahannya atau timbulnya variabel dependen (terikat). Variabel bebas (X) pada penelitian ini adalah kinerja petugas cleaning service.

2. Variabel terikat (dependent variable) yang merupakan variabel yang dipengaruhi atau yang menjadi akibat karena adanya variabel bebas. Variabel terikat $(\mathrm{Y})$ pada penelitian ini adalah kepuasan penumpang ekonomi KM. Kelud.

\section{Hasil dan Pembahasan}

Responden dalam penelitian ini adalah penumpang Kelas Ekonomi KM. Kelud PT. PELNI (Persero) sejumlah 90 orang dengan karakteristik responden meliputi usia, jenis kelamin, domisili, dan tingkat penghasilan yang dapat dilihat pada tabel berikut:

\section{a. Identitas Responden Berdasarkan Usia}

Tabel 3.1 karakteristik responden berdasarkan usia

\begin{tabular}{|l|c|c|}
\hline \multicolumn{1}{|c|}{ Usia } & Jumlah (f) & Prosentase (\%) \\
\hline$<20$ tahun & - & - \\
\hline $21-40$ tahun & 60 & $66,6 \%$ \\
\hline$>40$ tahun & 30 & $33,3 \%$ \\
\hline Jumlah & $\mathbf{9 0}$ & $\mathbf{1 0 0 \%}$ \\
\hline
\end{tabular}

Sumber: Data primer yang telah diolah, 2020

Dari tabel 3.1 dapat diketahui hasil pengelompokan terlihat kelompok di usia terbanyak yaitu responden dengan usia 21-40 tahun dengan jumlah 60 responden dan presentase 66,6\%. Dari 
deskripsi responden berdasarkan usia dapat disimpulkan bahwa penumpang KM. Kelud mayoritas berusia 21-40 tahun.

\section{b. Identitas Responden Berdasarkan Jenis Kelamin}

Tabel 3.2 Karakteristik Responden Berdasarkan Jenis Kelamin

\begin{tabular}{|c|c|c|}
\hline Jenis Kelamin & Jumlah (f) & Prosentase (\%) \\
\hline Laki-Laki & 50 & $55,5 \%$ \\
\hline Perempuan & 40 & $44,4 \%$ \\
\hline Jumlah & $\mathbf{9 0}$ & $\mathbf{1 0 0 \%}$ \\
\hline
\end{tabular}

Sumber: Data primer yang telah diolah, 2020

Hasil dari tabel 3.2 dapat diketahui bahwa jumlah responden terbanyak menurut jenis kelamin adalah laki-laki, yaitu 50 responden dengan presentase 55,5\%. Jadi didapat deskripsi bahwa penumpang kelas ekonomi KM. KELUD lebih didominasi oleh penumpang berjenis kelamin lakilaki.

\section{c. Identitas Responden Berdasarkan Domisili}

Tabel 3.3 Karakteristik Responden Berdasarkan Domisili

\begin{tabular}{|c|c|c|}
\hline Domisili & Jumlah (f) & Prosentase (\%) \\
\hline Jakarta & 20 & $22,2 \%$ \\
\hline Batam & 10 & $11,1 \%$ \\
\hline Medan & 60 & $66,6 \%$ \\
\hline Jumlah & $\mathbf{9 0}$ & $\mathbf{1 0 0 \%}$ \\
\hline
\end{tabular}

Sumber: Data primer yang telah diolah, 2020

Dari tabel 3.3 diketahui bahwa jumlah responden terbanyak berdomisili di Medan yaitu 60 responden dengan presentase $66,6 \%$. Jadi didapat deskripsi bahwa penumpang kelas ekonomi KM. KELUD didominasi oleh penumpang yang berdomisili di kota Medan.

\section{d. Identitas Responden Berdasarkan Tingkat Penghasilan}

Tabel 3.4 Karakteristik Responden Berdasarkan Penghasilan

\begin{tabular}{|l|c|c|}
\hline \multicolumn{1}{|c|}{ Penghasilan } & Jumlah (f) & Prosentase (\%) \\
\hline >1 Juta & 10 & $11,1 \%$ \\
\hline 1 Juta- 3 Juta & 60 & $66,6 \%$ \\
\hline$<3$ Juta & 20 & $22,2 \%$ \\
\hline Jumlah & $\mathbf{9 0}$ & $\mathbf{1 0 0 \%}$ \\
\hline
\end{tabular}

Sumber: Data primer yang telah diolah, 2020 
Dari tabel 3.4 diketahui bahwa jumlah responden terbanyak berpenghasilan Rp1 juta sampai dengan Rp3 juta, yaitu 60 responden dengan presentase 66,6\%. Jadi deskripsi responden penumpang kelas ekonomi KM. KELUD didominasi oleh penumpang yang berpenghasilan menengah ke bawah.

\section{e. Analisis Koefesien Korelasi Product Moment}

Tabel 3.5 Analisis Korelasi Product Moment

Correlations

\begin{tabular}{|c|c|c|c|}
\hline & & $\begin{array}{c}\mathrm{X} \\
\text { (Kinerja) }\end{array}$ & $\begin{array}{l}\text { Y (Kepuasan } \\
\text { Pelanggan) }\end{array}$ \\
\hline \multirow{4}{*}{ X (Kinerja) } & Pearson Correlation & 1 &, $718^{* *}$ \\
\hline & Sig. (2-tailed) & &, 000 \\
\hline & $\mathrm{N}$ & 90 & 90 \\
\hline & Pearson Correlation &, $718^{* *}$ & 1 \\
\hline \multirow[t]{2}{*}{ Y (Kepuasan Pelanggan) } & Sig. (2-tailed) & ,000 & \\
\hline & $\mathrm{N}$ & 90 & 90 \\
\hline
\end{tabular}

Berdasarkan hasil output software SPSS diperoleh nilai koefisien korelasi (R) sebesar 0,718. Hal ini menunjukkan bahwa terdapat hubungan yang kuat antara Kinerja (X) terhadap Kepuasan Pelanggan (Y).

\section{f. Analisis Koefesien Determinasi}

Analisis koefisien determinasi adalah analisis yang digunakan untuk mengetahui kekuatan Pengaruh Kinerja (X) terhadap Kepuasan Pelanggan (Y) dapat ditunjukkan oleh nilai R square (koefisien determinasi).

\section{Tabel 3.6 Koefisien Determinasi}

Model Summary ${ }^{b}$

\begin{tabular}{|l|r|r|r|r|}
\hline Model & $R$ & $R$ Square & \multicolumn{1}{|c|}{$\begin{array}{c}\text { Adjusted } R \\
\text { Square }\end{array}$} & $\begin{array}{c}\text { Std. Error of the } \\
\text { Estimate }\end{array}$ \\
\hline 1 &, $718^{\mathrm{a}}$ &, 516 &, 510 & 1,215 \\
\hline
\end{tabular}

a. Predictors: (Constant), X (Kinerja)

b. Dependent Variabel: Y (Kepuasan Pelanggan)

Sumber: Data primer yang telah diolah, 2020

Berdasarkan tabel diatas, nilai R square adalah 0,516 atau 51,6\%. Artinya variabel Kinerja (X) memberikan pengaruh kuat sebesar 51,6\% terhadap Kepuasan Pelanggan (Y). Sedangkan sisanya sebesar $48,4 \%$ merupakan kontribusi variabel lain selain Kinerja (X) 


\section{g. Analisis Regresi Linier Sederhana}

Pengaruh Kinerja (X) terhadap Kepuasan Pelanggan (Y).

Untuk melihat pengaruh Kinerja (X) terhadap Kepuasan Pelanggan (Y) digunakan analisis regresi linier sederhana dengan persamaan sebagai berikut:

$$
\mathbf{Y}=a+b x
$$

Di mana:

$\mathrm{Y}=$ Variabel independen sebagai variabel yang diduga atau diprediksi

$\mathrm{x}=$ Variabel Independen, nilai variabel yang diketahui

$\mathrm{a}=$ Koefisiensi seebagai intersep

Jjika nilai $X=0$, maka nilai $Y=a$. Nilai a ini dapat diartikan sebagai sumbangan faktor-faktor lain terhadap variabel $\mathrm{Y}$.

Hasil pengolahan software SPSS 20 untuk analisis regresi sederhana disajikan pada tabel berikut:

Tabel 3.7 Regresi Sederhana

Coefficients $^{a}$

\begin{tabular}{|c|c|c|c|c|c|}
\hline \multirow[t]{2}{*}{ Model } & \multicolumn{2}{|c|}{ Unstandardized Coefficients } & \multirow{2}{*}{$\begin{array}{c}\begin{array}{c}\text { Standardized } \\
\text { Coefficients }\end{array} \\
\text { Beta }\end{array}$} & \multirow[t]{2}{*}{$\mathrm{T}$} & \multirow[t]{2}{*}{ Sig. } \\
\hline & B & Std. Error & & & \\
\hline (Constant) & 7,442 & 2,265 & & 3,286 & ,001 \\
\hline $\mathrm{X}$ (Kinerja) & ,746 & 077 & ,718 & 9,686 &, 000 \\
\hline
\end{tabular}

a. Dependent Variabel: Y (Kepuasan Pelanggan)

Sumber: Data primer yang telah diolah, 2020

Berdasarkan hasil perhitungan pada tabel di atas, diperoleh bentuk persamaan regresi linier sederhana sebagai berikut:

$$
Y=7,442+0,746 X
$$

Nilai koefisien regresi pada variabel-variabel independennya menggambarkan apabila diperkirakan variabel independennya naik sebesar satu unit dan nilai variabel independen lainnya diperkirakan konstan atau sama dengan nol, maka nilai variabel terikat diperkirakan bisa naik atau bisa turun sesuai dengan tanda koefisien regresi variabel independennya.

Dari persamaan regresi linier sederhana diatas diperoleh nilai konstanta sebesar 7,442. Artinya, jika variabel Kepuasan Pelanggan (Y) tidak dipengaruhi oleh variabel independennya yaitu Kinerja (X) akan bernilai 7,442.

Tanda koefisien regresi variabel independen menunjukkan arah hubungan dari variabel yang bersangkutan dengan Kepuasan Pelanggan (Y). Koefisien regresi untuk variabel independen $\mathrm{X}$ bernilai positif, menunjukkan adanya hubungan yang searah antara Kinerja (X) dengan Kepuasan Pelanggan (Y). Koefisien regresi variabel $\mathrm{X}$ sebesar 0,746 mengandung arti untuk setiap 
pertambahan Kinerja (X) sebesar satu satuan akan menyebabkan meningkatkan Kepuasan Pelanggan (Y) sebesar 0,746.

\section{h. Uji Hipotesis}

Pengujian hipotesis secara parsial (Uji t)

Untuk mengetahui signifikan atau tidaknya pengaruh antara variabel $\mathrm{X}$ dan variabel $\mathrm{Y}$, maka pengujian hipotesis dilakukan dengan menggunakan rumus uji t.

Untuk pengujian pengaruh parsial digunakan rumusan hipotesis sebagai berikut:

$\mathrm{H}_{1}=$ Terdapat Pengaruh Kinerja (X) terhadap Kepuasan Pelanggan (Y).

$\mathrm{H}_{0}=$ Tidak terdapat Pengaruh Kinerja (X) terhadap Kepuasan Pelanggan (Y)

Kriteria uji:

$\mathrm{t}_{\text {hitung }}<\mathrm{t}_{\text {tabel }}=\mathrm{H}_{\mathrm{o}}$ diterima dan $\mathrm{H}_{1}$ ditolak

$\mathrm{t}_{\text {hitung }}>\mathrm{t}_{\text {tabel }}=\mathrm{H}_{\mathrm{o}}$ ditolak dan $\mathrm{H}_{1}$ diterima

\section{Tabel 3.8 Uji Parsial}

Coefficients $^{\mathbf{a}}$

\begin{tabular}{|rr|r|r|r|r|r|}
\hline \multicolumn{2}{|l|}{ Model } & \multicolumn{2}{|c|}{ Unstandardized Coefficients } & \multicolumn{1}{|c|}{$\begin{array}{c}\text { Standardized } \\
\text { Coefficients }\end{array}$} & \multicolumn{1}{|c|}{ Sig. } \\
\cline { 2 - 5 } & \multicolumn{1}{|c|}{ B } & Std. Error & Beta & & \\
\hline \multirow{2}{*}{1} & (Constant) & 7,442 & 2,265 & & 3,286 &, 001 \\
& X (Kinerja) &, 746 &, 077 &, 718 & 9,686 &, 000 \\
\hline
\end{tabular}

a. Dependent Variabel: Y (Kepuasan Pelanggan)

Sumber: Data primer yang telah diolah, 2020

Berdasarkan tabel di atas, Variabel Kinerja (X) memiliki nilai t hitung sebesar 9,686, pada tingkat kesalahan (alpha) 0,05 dengan jumlah sampel 90 dan jumlah variabel bebas 1 maka nilai $\mathrm{t}$ tabel adalah $(1,987)$. Karena nilai t hitungnya $(9,686)$ lebih besar dari t tabel $(1,987)$ maka H1 diterima, artinya terdapat pengaruh antara Kinerja (X) terhadap Kepuasan Pelanggan (Y).

Pada penelitian ini, 90 (sembilan puluh) pernyataan kuesioner dari 2 (dua) variabel, yaitu Kinerja (X) dan Kepuasan Pelanggan (Y) telah dibagikan kepada 90 (sembilan puluh) responden yaitu penumpang ekonomi KM. Kelud PT. PELNI (Persero).

Berdasarkan dari frekuensi tanggapan responden pada indikator variabel Kinerja dan Kepuasan Pelanggan, pada variabel Kinerja maupun Kepuasan Pelanggan didapat hasil terbanyak ialah pada nilai "Setuju" setelah itu "Sangat Setuju", namun masih ada beberapa responden yang menjawab "Kurang Setuju" pada 7 indikator yang ditanyakan. Berdasarkan dari hasil rekapitulasi pada variabel Kinerja didapat hasil rata-rata sebesar 4,16 untuk hal ini dinilai baik, namun sayangnya masih ada 5 indikator yang nilainya berada dibawah rata-rata, sedangkan pada variabel kepuasan pelanggan didapat hasil rata-rata sebesar 4,06 untuk hal ini dinilai baik, namun sayangnya masih ada 2 indikator yang nilainya berada di bawah rata-rata. Hal tersebut menunjukkan bahwa Kinerja Petugas Cleaning Service pada kepuasan penumpang ekonomi di KM. Kelud sudah baik namun harus ditingkatkan kembali.

Selain itu, peneliti juga menganalisis uji hipotesis yang terdiri dari Regresi Linier Sederhana dan Uji T untuk mengetahui seberapa besar pengaruh variabel kinerja terhadap kepuasan pelanggan. Dari hasil uji tersebut didapatkan hasil uji hipotesis X yang menunjukan bahwa t hitung sebesar $9,686>t$ 
tabel 1.987 pada tingkat kesalahan (alpha) sebesar 0,05. Dari hasil tersebut dapat disimpulkan bahwa variabel kinerja petugas cleaning service berpengaruh secara signifikan terhadap kepuasan penumpang ekonomi KM. Kelud PT. PELNI (Persero).

Mangkunegara (2013:75) mengemukakan bahwa indikator kinerja, yaitu: Kualitas (Kinerja adalah seberapa baik seorang karyawan mengerjakan apa yang seharusnya dikerjakan), Kuantitas (Kuantitas kerja adalah seberapa lama seorang pegawai bekerja dalam harinya. Kuantitas kerja ini dapat dilihat dari kecepatan kerja setiap pegawai), Pelaksanaan Tugas (Pelaksanaan tugas adalah seberapa jauh karyawan mampu melakukan pekerjaannya dengan akurat atau tidak ada kesalahan), berpengaruh sebesar 0,516 atau $51,6 \%$. Sedangkan sisanya sebesar $48,4 \%$ merupakan kontribusi faktor-faktor lain yang tidak dimasukkan ke dalam penelitian ini. Hasil tersebut diperoleh dari pengujian koefisien determinasi untuk mengetahui kemampuan variabel independen yaitu Kinerja dalam menjelaskan variabel dependen yaitu kepuasan pelanggan. Hasil tersebut memberikan pengertian bahwa variabel dependen yaitu Kinerja dapat dijelaskan oleh variabel independen yaitu Kepuasan Pelanggan.

Hasil penelitian ini memberikan makna bahwa knerja merupakan suatu pendekatan baru yang membantu manajemen perusahaan untuk mencapai kepuasan pelanggan. Selanjutnya, kepuasan pelanggan berpengaruh secara signifikan terhadap kepercayaan pelanggan, dan kemudian kepercayaan pelanggan berpengaruh secara signifikan terhadap kesetiaan pelanggan, sisanya berarti dipengaruhi oleh faktor-faktor lain yang tidak dibahas pada penelitian ini.

Selain itu hasil penelitian ini menunjukan bahwa 1. Kualitas pelayanan (X1) berpengaruh secara positif dan signifikan terhadap kepuasan pelanggan, 2. Kinerja Cleaning Service (X2) berpengaruh secara positif dan signifikan terhadap kepuasan pelanggan, 3. Kualitas pelayanan dan kinerja Cleaning Service secara simultan berpengaruh terhadap kepuasan pelanggan. Pengaruh Kinerja Karyawan Terhadap Kepuasan Konsumen menunjukan bahwa kinerja karyawan dalam kategori baik. Sesuai dengan hasil analisis diperoleh variabel kinerja karyawan memiliki koefesien regresi sebesar 0,197 (bertanda positif terhadap kepuasan konsumen (Y) dan nilai t hitung sebesar 2,318 dengan tingkat signifikasi $0,023<0,05)$. Hal ini berarti bahwa Kinerja Karyawan berpengaruh positif terhadap Kepuasan Konsumen.

Berdasarkan hasil observasi pada saat melakukan penelitian di KM. Kelud terutama di lingkup pekerjaan cleaning service area penumpang ekonomi, petugas telah bekerja sesuai dengan prosedur yang berlaku, fasilitas kebersihan terawat dengan cukup baik, suasana bersih dan nyaman. Keadaan ini yang membuat pelanggan merasa aman dan yakin untuk memilih KM. Kelud PT. PELNI (Persero).

\section{Kesimpulan dan Saran}

\subsection{Kesimpulan}

Berdasarkan hasil analisis yang telah dilakukan, maka diambil kesimpulan sebagai berikut:

- Berdasarkan hasil uji Koefisien Determinasi (R2) diperoleh hasil bahwa variabel dependen yaitu Kinerja mempengaruhi variabel Independen, yaitu kepuasan Pelanggan dengan nilai sebesar sebesar 51,6\%. Hal tersebut menunjukkan bahwa variabel Kinerja Petugas Cleaning Service berpengaruh positif dan signifikan terhadap kepuasan penumpang ekonomi KM. Kelud PT. PELNI (Persero).

- Hasil Uji T pada penelitian ini memiliki nilai t hitung sebesar 9,686. pada tingkat kesalahan (alpha) 0,05 dengan jumlah sampel 90 dan jumlah variabel bebas 1 maka nilai t tabel adalah $(1,987)$. Karena nilai t hitungnya $(9,686)$ lebih besar dari t tabel $(1,987)$ maka H1 diterima, artinya terdapat pengaruh antara Kinerja (X) terhadap Kepuasan Pelanggan (Y).

- Selain itu peneliti juga mendapatkan hasil dari Uji Regresi Linier Sederhana, dari uji tersebut peneliti memperoleh hasil bahwa nilai koefisien regresi (X) sebesar 0,746 mengandung arti untuk setiap pertambahan Kinerja (X) sebesar satu satuan akan menyebabkan meningkatnya Kepuasan Pelanggan (Y) sebesar 0,746. Hal ini memberikan arti bahwa Kinerja Petugas 
Cleaning Service (X) berpengaruh terhadap kepuasan penumpang ekonomi KM. Kelud

\subsection{Saran}

PT. PELNI (Persero) (Y).

Untuk variabel Kinerja Petugas cleaning service, yaitu:

- PT. PELNI (Persero) terus melakukan pelatihan secara bidang pengelolaan kebersihan ke seluruh petugas cleaning service sehingga kemampuan dan keterampilan petugas cleaning service semakin meningkat.

- PT. PELNI (Persero) selalu mengingatkan dan tidak segan memberi teguran kepada petugas cleaning service yang lalai dan tidak melaksanakan pekerjaan sesuai dengan SOP yang berlaku.

- PT. PELNI (Persero) senantiasa memberikan pengarahan dan melakukan tindak tegas kepada petugas cleaning service yang tidak melaksanakan tugas secara disiplin dan sesuai jadwal.

- PT. PELNI (Persero) selalu mengimbau kepada mandor cleaning service untuk dapat memastikan dan melakukan pengecekan hasil kerja bawahannya secara rutin dan berkala agar pekerjaan bisa selesai sesuai dengan service level agreement yang telah ditentukan.

- PT. PELNI (Persero) terus mengimbau ke setiap petugas cleaning service agar senantiasa bekerja dengan tulus dan senantiasa melakukan improvisasi dalam menghadapi permasalahan yang timbul serta terus berusaha memberikan solusi terbaik pada setiap permasalahan yang dialami oleh pelanggan.

Untuk variabel Kepuasan Penumpang adalah:

- PT. PELNI (Persero) terus berupaya menjaga hubungan baik dengan pelanggan serta senantiasa mengapresiasi loyal customers sehingga pelanggan tidak beralih ke kompetitor atau moda transportasi lain.

- PT. PELNI (Persero) senantiasa memastikan semua fasilitas kebersihan di semua kapal penumpang dapat dinikmati secara gratis dan tidak dipungut biaya, dan menindak tegas pelaku pungli yang meresahkan penumpang.

\section{Referensi}

Buku:

Andriansyah. 2015. Manajemen Trasnportasi Dalam Kajian Dan Teori. Jakarta: Fakultas Ilmu Sosial Dan Ilmu Politik Universitas Prof. Dr. Moestopo Beragama

Conciere Oxford Dictionary. 2017. Definisi Hospitality Dalam Bahasa Inggris. Jakarta : PT. Gramedia.

Hermawan, Herry. 2017. Pengantar Manajemen Hospitality (Edisi lengkap). Jakarat: PT. Nasya Expanding Manajemen.

HES Indonesia. 2017. Pengertian Cleaning Service. Jakarta: PT. Hygienis Enviromental Service Indonsia.

Kotler, 2012. Bagaimana Menciptakan, Memenangi dan Mendominasi Pasar. Jakarta: Kharisma Publishinng Group.

Mangkunegara, Anwar Prabu. 2013. Evaluasi Kinerja Sumber Daya Manusia. Bandung: Rafika Adita.

Pandit. S. 2017. Ilmu Pariwisata : Sebuah Pengantar Perdana. Jakarta: Pradnya Paramita.

Rambat Lupiyoadi. 2014. Manajemen Pemasaran Jasa Edisi 2. Jakarta : Salemba Empat. 
Sugiyono. 2010. Metode Penelitian Pendidikan Pendekatan Kuantitatif, kualitatif, dan R\&D. Bandung: Alfabeta.

Sugiyono. 2014. Metodelogi Penelitian Kuantitatif, Kualitatif Dan R\&D. Bandung: Alfabeta

Tjiptono, Fandy. 2011. Service Management Mewujudkan Layanan Prima. Edisi 2. Yogyakarta: Andi.

Tjiptono, Fandy. 2014. Pelanggan Puas? Mana Cukup!. Yogyakarta: Andi.

Tim Dosen STP Nusa Dua Bali. 2016. Pengantar Ilmu Pariwisata. Bali : Sekolah Tinggi Pariwisata Nusa Dua Bali.

\section{Peraturan Pemerintah:}

Peraturan Pemerintah Republik Indonesia. 2010. Tentang Angkutan Perairan, kapal laut angkutan penumpang adalah kegiatan angkutan yang menurut kegiatannya melayani angkutan laut baik dalam negeri maupun luar negeri. Jakarta: Pemerintah Republik Indoonesia

Peraturan Menteri Perhubungan Nomor 115. 2016, Pengertian kapal adalah kendaraan air dengan bentuk dan jenis tertentu. Jakarta: Kementerian Perhubungan Republik Indonesia.

\section{Jurnal:}

Subchi Fahat. Mohamad. 2017. Pengaruh Disiplin Kerja Terhadap Kinerja Karyawan Cleaning Service PT.ISS Indonesia di Samarinda (Studi kasus pada Samarinda Central Plaza). eJurnal administrasi bisnis vol 52017.

Idahwati, S.E., M.Si. 2018. Pengaruh Kualitas Pelayanan dan Kinerja Cleaning Service Terhadap Kepuasan Pelanggan PT.ISS Indonesia (Studi kasus pada mahasiswa Akademi Kebidanan Sari Mutiara Medan. Jurnal Mutiara Manajemen Vol 3 No 12018.

Kattara, Dr. Saad Hanan. 2015. The impact of employees' behavior on customers' service quality perceptions and overall satisfaction. African Journal of Hospitality, Tourism and Leisure Vol 42015

Pantja Djati. S. 2019. Pengaruh Kinerja Karyawan Terhadap Kepuasan, Kepercayaan dan Kesetiaan Pelanggan. Jurnal Manajemen Ekonomi Vol 12019.

Sasongko Noer. 2017. Pengaruh Kualitas Layanan dan Kinerja Karyawan Terhadap Kepuasan Pelanggan (Studi Pada Universitas Muhammadiyah Surakarta). e-Jurnal Profesi Akuntansi UMS 2017.

Virgiawansyah Eno. 2017. Pengaruh Kinerja Karyawan Terhadap Kepuasan Konsumen. Jurnal pendidikan ekonomi FKIP UNTAN 2017. 